\title{
Коарктація аорти у новонароджених і немовлят: балонна ангіопластика чи хірургічне лікування?
}

\author{
Труба Я. П., Дітківський І. О., Іманов Е. М., Плиска О. І., Мошківська Л. В., \\ Дзюрій І. В., Головенко О. С., Лазоришинець В. В.
}

ДУ «Національний інститут серцево-судинної хірургії імені М. М. Амосова НАМН України» (Київ)

\begin{abstract}
Коарктація аорти (КоА) - це вроджений дискретний стеноз проксимального відділу низхідної грудної аорти, який часто стає причиною критичного стану малюків. Методами лікування в даній віковій групі є балонна ангіопластика і хірургічна корекція. Балонна ангіопластика - малоінвазивний спосіб корекції дискретної коарктації, але цей метод залишається суперечливим як стратегія первинної терапії.
\end{abstract}

Мета дослідження - порівняння ефективності і результатів балонної ангіопластики та хірургічного корекції коарктації аорти у немовлят.

Матеріали і методи. У період 2007 по 2018 рік у ДУ «Національний інститут серцево-судинної хірургії імені М. М. Амосова НАМН України» проліковано 155 пацієнтів із коарктацією аорти. Середній вік пацієнтів становив 3,2 1,4 міс. (від 0 до 12 міс.), середня маса $-5,3 \pm 1,7$ кг (від 2 до 10 кг). Пацієнти були розділені на дві групи: перша група - 78 пацієнтів, яким виконали балонну дилатацію коарктації аорти; друга група 77 пацієнтів, яким виконали хірургічну корекцію. Пацієнти з комплексними супутніми внутрішньосерцевими аномаліями серця не були включені до цього дослідження.

Результати. Аналіз безпосередніх результатів не виявив суттєвої різниці в ефективності двох методів $(\mathrm{p}=0,17)$. В той же час відсоток рекоарктації був значно нижчим у групі хірургічного лікування (3 випадки $(3,8 \%)$ проти $32(41 \%)$ у групі балонної дилатації, $\mathrm{p}<0,05)$. Середній термін перебування в лікарні статистично відрізнявся і становив $6,7 \pm 3,2$ дня в групі ангіопластики та $21,4 \pm 8,1$ дня у групі хірургічного лікування $(\mathrm{p}<0,05)$. Аневризм у місці корекції не було виявлено в обох групах.

Висновки. Як хірургічна корекція, так і балонна ангіопластика коарктації аорти у немовлят були ефективними і мали добрий безпосередній результат. Проведене дослідження вказує на те, що балонна ангіопластика становить прийнятну альтернативу хірургічному лікуванню, однак через високий рівень рекоарктації цей метод може бути використаний переважно у хворих із критичною коарктацією аорти, ознаками вираженої серцевої недостатності та низькою фракцією викиду лівого шлуночка як паліативна процедура.

Ключові слова: коарктація аорти, балонна ангіопластика, немовлята.

Коарктація аорти у новонароджених і грудних дітей - це порушення нормального розвитку аорти в перинатальному періоді у вигляді формування обмеженого, локального внутрішньопросвітного звуження аорти в проекції іiї перешийка у вигляді піскового годинника або діафрагми з невеликим отвором. Коарктація аорти є однією з найпоширеніших вроджених вад серця, що виникає у 4-6\% пацієнтів із вродженими захворюваннями серця, при цьому пацієнти чоловічої статі хворіють частіше, ніж жіночої [1]. Ця аномалія була описана Йоханнесом Моргані в 1761 році [2]. Перша хірургічна корекція КоА виконана у 1944 році С. Крафордом та Д. Ніліном, і впродовж 40 років хірургічний метод залишався практично безальтернативним. У 1983 році 3. Лабабіді здійснив першу транскатетерну ангіопластику коарктації аорти $[1,2,6]$. Незважаючи на багаторічний досвід лікування цієї вади, оптимальна тактика лікування КоА у немовлят все ще залишається суперечливою.
Матеріали та методи. У період з 2007 по 2018 рік у ДУ «Національний інститут серцево-судинної хірургії імені М. М. Амосова НАМН України» проліковано 155 послідовних пацієнтів віком до 1 року з коарктацією аорти. Середній вік пацієнтів становив $3,2 \pm 1,4$ міс. (від 0 до 12 міс.), середня маса $-5,3 \pm 1,7$ кг (від 2 до 10 кг). Пацієнти були розділені на дві групи відповідно до типу лікування. Перша група - 78 пацієнтів, яким виконали балонну ангіопластику. Друга група - 77 пацієнтів, яким первинно виконали хірургічну корекцію. Усім госпіталізованим в ДУ «Національний інститут серцево-судинної хірургії імені М. М. Амосова НАМН України» пацієнтам було проведено комплексне обстеження, яке включало: анамнез, загальноклінічні методи включно з лабораторними обстеженнями (загальний і біохімічний аналіз крові, дослідження системи гемостазу, клінічний аналіз сечі, газовий склад крові), електрокардіографію в стандартних і грудних відведеннях, рентгенографію грудної клітки, комплексне 
ехокардіографічне обстеження в одномірному і двомірному режимі з використанням кольорової доплерографії. Усім пацієнтам перед операцією проводили нейросонографію для виключення патологічних змін головного мозку. КоА діагностували на підставі комбінації клінічних ознак (градієнт артеріального тиску між верхніми і нижніми кінцівками $>20$ мм рт. ст., відсутній або ослаблений пульс на стегнових артеріях) i типових ознак КоА під час доплерівського ехокардіографічного обстеження. Якщо під час обстеження виявляли дискретну коарктацію, а пацієнт мав ознаки вираженої серцевої недостатності, то як паліативну процедуру, що давала можливість пережити критичний період і стабілізувати хворого, було рекомендовано проведення ангіопластики. Починали ангіопластику, використовуючи балони діаметром, рівним діаметру перешийка аорти або сегменту В дуги аорти.

Порівняльна характеристика пацієнтів, включаючи вік, стать, вагу, артеріальний тиск, наведена в табл. 1.

Балонну ангіопластику здійснювали за стандартною методикою. Усі процедури проводили, комбінуючи місцеву анестезію лідокаїном з в/в уведенням кетаміну (1 мг/кг/дози) для седації. Усі пацієнти отримували антибіотикопрофілактику. Для профілактики тромбоемболічних ускладнень уводили в/в гепарин (100 Од./кг). Методика включала імплантування стента доступом через пункцію стегнової артерії, через який заводили інтродьюсер 4F. Через останній в Ао заводили балон 5-7 мм. Катетер вводили в низхідну аорту і замірювали кров'яний тиск дистальніше іії звуження. Надалі проводили катетер через КоА у висхідну Ао і виконували аортографію у проекції LAD $30^{\circ}$ і боковій проекції. Обирали балон діаметром, рівним сегменту В дуги аорти. Дилатацію проводили під тиском 2 атм. Успіхом вважали зменшення градієнта систолічного тиску в місці КоА до рівня <20 мм рт. ст.

При хірургічному лікуванні в усіх пацієнтів проводили латеральну торакотомію в 3-му міжребер'ї зліва. Низхідну Ао, ліву підключичну і каротидну артерії виділяли і мобілізували. Артеріальну протоку прошивали

\section{Таблиця 1}

Характеристика пацієнтів

\begin{tabular}{lccc} 
& $\begin{array}{c}\text { Група 1 } \\
\text { Балонна } \\
\text { ангіопластика } \\
\text { (n=78) }\end{array}$ & $\begin{array}{c}\text { Група 2 } \\
\text { Хірургія } \\
\text { Показник }\end{array}$ & $\mathbf{p}$ \\
\hline Жін./чол. & $26 / 52$ & $27 / 50$ & 0,3 \\
\hline Вік (міс.) & $2,4 \pm 1,7$ & $4,3 \pm 2,1$ & 0,09 \\
\hline Вага (кг) & $4,2 \pm 1,4$ & $6,5 \pm 2,3$ & 0,2 \\
\hline Градієнт тиску & $64,3 \pm 17,3$ & $59,2 \pm 11,3$ & 0,56 \\
(Мм рт.ст.) & & & \\
\hline Фракція викиду (\%) & $46,4 \pm 9,3$ & $64,2 \pm 8,3$ & $<0,05$
\end{tabular}

\section{Таблиця 2}

Порівняння результатів лікування в досліджуваних груnах

\begin{tabular}{lccc} 
& $\begin{array}{c}\text { Група 1 } \\
\text { Балонна } \\
\text { aнгіопластика } \\
\text { (n=78) }\end{array}$ & $\begin{array}{c}\text { Група 2 } \\
\text { Хipypriя } \\
\text { (n=77) }\end{array}$ & p \\
\hline Показники & $64,3 \pm 17,3$ & $59,2 \pm 11,3$ & 0,08 \\
\hline $\begin{array}{l}\text { Градієнт систолічного } \\
\text { тиСку (ГСТ) (мм рт. ст.) }\end{array}$ & $18,5 \pm 6,4$ & $14,3 \pm 4,4$ & 0,17 \\
\hline $\begin{array}{l}\text { ГСТ безпосередньо після } \\
\text { процедури }\end{array}$ & $41,4 \pm 11,3$ & $15,7 \pm 6,4$ & $<0,05$ \\
\hline ГСТ через 6 міс. & $47,3 \pm 16,4$ & $17,5 \pm 8,7$ & $<0,05$ \\
\hline ГСТ через 12 міс. & $62 \pm 4,3$ & $67 \pm 2,9$ & 0,26 \\
\hline $\begin{array}{l}\text { Фракція викиду на мо- } \\
\text { мент виписки (\%) }\end{array}$ & $6,7 \pm 3,2$ & $21,4 \pm 8,1$ & $<0,05$ \\
\hline $\begin{array}{l}\text { Перебування в стаціонарі } \\
\text { (дні) }\end{array}$ & $32(41 \%)$ & $3(3,8 \%)$ & $<0,05$ \\
\hline $\begin{array}{l}\text { Повторні втручання через } \\
\text { рекоарктацію (1-й рік) }\end{array}$ & 0 & 0 & - \\
\hline Госпітальна летальність & 0 & &
\end{tabular}

і пересікали. При дисекції стенотичного сегмента Ао обережно відділяли навколопротокові тканини. Вирізали стенотичний сегмент Ао і простим «кінець у кінець» анастомозом з'єднували резектовані краї в усіх дітей, що не мали гіпоплазії проксимальної або дистальної дуги аорти. За наявності гіпоплазованої дуги аорти проводили резекцію з накладанням розширеного анастомозу «кінець у кінець» до аортальної дуги.

Результати та обговорення. В обох досліджуваних групах летальних випадків не було. Порівняльні результати дослідження наведено в табл. 2. Середній градієнт тиску в групі 1 зменшився з 64,3 $\pm 17,3$ до $18,5 \pm 6,4$ мм рт. ст. після операції $(\mathrm{p}<0,05)$. У групі 2 середній градієнт тиску знизився з 59,2士11,3 до $14,3 \pm 4,4$ мм рт. ст. $(\mathrm{p}<0,05)$. Середня тривалість перебування в стаціонарі дорівнювала $6,7 \pm 3,2$ дня в групі ангіопластики і $21,4 \pm 8,1$ дня у хірургічній групі, що становить значну статистичну різницю $(\mathrm{p}<0,05)$.

Всі ускладнення госпітального етапу в групах порівняння наведено в табл. 3 .

Для доступу до стегнової артерії в одного пацієнта після невдалої перкутанної спроби було виконано артеріосекцію. При подальшому спостереженні обидві нижні кінцівки розвивались однаково. Два пацієнти мали хілоторакс після хірургічної аортопластики, що спонукало до тривалого дренування плевральної порожнини. Всі пацієнти лікувалися консервативно. У групі балонної ангіопластики жоден пацієнт не потребував переливання компонентів крові. У хірургічній групі 4 хворих мали анемію, що вимагала переливання крові після хірургічного втручання. У 7 пацієнтів хірургічної групи виявлено частковий ателектаз легень, 


\section{Таблиця 3}

Ускладнення госпітального еmany

\begin{tabular}{lccc} 
Урупа 1 & $\begin{array}{c}\text { Галонна } \\
\text { ангіопластика } \\
\text { (n=78) }\end{array}$ & $\begin{array}{c}\text { Група 2 } \\
\text { Хірургія } \\
\text { (n=77) }\end{array}$ & p \\
\hline Надрив інтими & 2 & 0 & - \\
\hline Хілоторакс & 0 & 2 & - \\
\hline Ранова інфекція & 0 & 3 & - \\
\hline $\begin{array}{l}\text { Формування аневризм } \\
\text { у зоні втручання }\end{array}$ & 0 & 0 & - \\
\hline $\begin{array}{l}\text { Часткові ателектази } \\
\text { легень }\end{array}$ & 3 & 7 & - \\
\hline Гемотрансфузії & 0 & 4 & - \\
\hline Усього & $\mathbf{5}$ & $\mathbf{1 6}$ & $<0,05$
\end{tabular}

у 3 - ранову інфекцію. Загалом 20,7\% пацієнтів хірургічної групи мали принаймні одне ускладнення після операції порівняно з 6,4\% пацієнтів групи балонної ангіопластики $(\mathrm{p}<0,05)$.

Середній термін спостереження у віддаленому періоді склав 19 міс. (8-48 міс.). Ехокардіографія була використана для вимірювання динаміки градієнта тиску в зоні корекції через кожні 6-12 місяців або за наявності послаблення стегнового пульсу при спостереженні. Рекоарктацію визначали, коли градієнт тиску перевищував 25 мм рт. ст. при вимірюванні трансторакальною ехокардіографією та $>20$ мм рт. ст. під час подальшої катетеризації серця.

У першій групі рекоарктація була визначена у 32 (41\%) хворих. Усі рекоарктації були локалізовані на місці балонного втручання, без поширення стенозу на перешийок. У всіх цих пацієнтів рекоарктація проявилась у перші 3-4 місяці після первинного втручання. Усім таким хворим виконано радикальну хірургічну корекцію. У другій групі рекоарктація була виявлена у $3(3,8 \%)$ пацієнтів і локалізована в зоні анастомозу. Гіпоплазії перешийка аорти та дуги у них не було. Пацієнтам успішно виконано повторну балонну ангіопластику.

Обговорення. Хірургічна корекція забезпечує добрі результати лікування пацієнтів із коарктацією аорти з того часу, коли С. Крафорд описав першу успішну корекцію цієї вади в 1946 році [1, 2]. Балонна ангіопластика була запропонована як альтернатива класичній операції при первинному лікуванні КоА в 1982 році $[1,2]$. Незважаючи на невтішні результати балонної дилатації у початкових звітах, подальший досвід $€$ більш оптимістичним. Проте кількість досліджень, що порівнюють балонну ангіопластику з хірургічним лікуванням, обмежена. Значущого зниження систолічного градієнта можна досягти як при хірургії, так і при ангіопластиці $[2,4,5]$. Рівень госпітальної летальності також був подібним, але після балонної ангіопластики виявлено більш високу частоту рекоарктації у немовлят порівняно з хірургічним лікуванням [3-5].

Відомо, що рекоарктація у віддаленому періоді після хірургічного лікування виникає у 10-30\% [2-6]. В той же час рестеноз після балонної ангіопластики спостерігався в $11-60 \%[1,2,4,5]$. Така розбіжність може залежати від конкретних аспектів хірургічної ангіопластичної техніки. Можливо, механізми розвитку рекоарктації, полягають в неадекватному рості анастомозу, активному фіброзі та звуженні в ділянці анастомозу, тромбозі на лінії шва та залишку аномальної дуктальної тканини.

У нашому дослідженні балонна ангіопластика є досить успішною, з хорошими безпосередніми результатами, низькою частотою ускладнень і коротким терміном перебування в стаціонарі. Негативним моментом є високий рівень рекоарктації при використанні цього методу. Ці результати дають нам право стверджувати, що балонна ангіопластика може бути ефективно застосована у симптоматичних хворих із критичною коарктацією. Подібний досвід також описаний іншими дослідниками [4-6].

Висновки. Власний досвід свідчить про те, що і хірургічна корекція, і балонна ангіопластика коарктації аорти у немовлят є ефективними і дають добрі безпосередні результати. Балонна ангіопластика може бути прийнятною альтернативою хірургічному лікуванню у немовлят з критичною коарктацією аорти, хоча і супроводжується підвищеним рівнем рекоарктації. Рекоарктація після балонної дилатації проявляється у перші 3-4 місяці післяопераційного спостереження і потребує повторної корекції хірургічним або ендоваскулярним способом.

\section{Література}

1. Alaei F, Moghadam MY, Mortaezaian H, Alaei M, Bakhshandeh H. Balloon Angioplasty versus Surgical Repair of Coarctation of Aorta in Infants. J Teh Univ Heart Ctr. 2011;6(3):134-7.

2. Walhout RJ, Lekkerkerker JC, Oron GH, Bennink GB, Meijboom EJ. Comparison of surgical repair with balloon angioplasty for native coarctation in patients from 3 months to 16 years of age. European Journal of Cardiothoracic Surgery. 2004;25(5):722-7.

3. Lee CL, Lin JF, Hsieh KS, Lin CC, Huang TC. Balloon Angioplasty of Native Coarctation and Comparison of Patients Younger and Older Than 3 Months. Circ J. 2007;71:1781-4.

4. Lin Sh-M, Hwang H-K, Wu Sh-J, Chen M-R. Comparison Between Balloon Angioplasty and Surgery for Native Coarctation of the Aorta in Neonates and Young Infants. Interventional Cardiology. Acta Cardiol Sin. 2008;24:204-8.

5. Chiu H-H, Wang J-K, Chen Y-Sh, Chiu I-Sh, Chang Ch-I, Lin M-T, Lu Ch-W, Chiu Sh-N, Chen Ch-A, Wu M-H. Long-Term Outcomes of Native Coarctation of 
the Aorta after Balloon Angioplasty or Surgical Aortoplasty in Newborns and Young Infants Less Than 3 Months of Age. Acta Cardiol Sin. 2013;29:168-74.
6. Suradi H, Hijazi ZM. Current management of coarctation of the aorta. Global Cardiology Science and Practice. 2015;2015(4):44. https://doi.org/10.5339/gcsp.2015.44.

\title{
Aortic Coarctation in Neonates and Infants: Balloon Angioplasty or Surgical treatment?
}

\author{
Truba Y., Dytkivski I., Imanov E., Plyska O., Moshkyvska L., Dzuriy I., Golovenko O., Lazoryshynetz V. \\ M. M. Amosov National Institute of Cardiovascular Surgery, National Academy of Medical Sciences of Ukraine (Kyiv)
}

Coarctation of the aorta $(\mathrm{CoA})$ is a discrete stenosis of the proximal thoracic aorta. The common clinical pattern is congestive heart failure in infancy. Treatment methods include balloon angioplasty (BA) and surgical repair in this age group. Percutaneous balloon angioplasty is a less invasive method for the repair of discrete coarctation but remains controversial as a primary treatment strategy for a native coarctation. This study aimed at comparing the efficacy and outcome of balloon angioplasty and surgical repair in infants with aortic coarctation younger than one year old.

Methods. Between January 2007 and December 2018, 155 patients with native aortic coarctation were treated in M.M. Amosov National Institute of Cardiovascular Surgery. This retrospective study evaluated the results of the two methods in patients younger than one year old with the diagnosis of aortic coarctation. Group 1 included 78 patients following balloon dilatation for discrete coarctation. Group 2 included 77 patients following surgical resection with end-to-end anastomosis. Patients with complex cardiac anomalies were not included in this study.

Results. Immediate results revealed no significant difference in the efficacy of the two methods $(p=0.17)$, with the rate of recurrent coarctation significantly lower in the surgery group [3 (3.8\%) vs. $32(41 \%), \mathrm{p}<0.05]$. The mean hospital stay was $6.7 \pm 3.2$ days in the balloon angioplasty group and $21.4 \pm 8.1$ days in the surgery group, which constitutes a significant statistical difference $(\mathrm{p}<0.05)$. Aneurysm formation was not reported.

Conclusion. Our own experience testifies that both surgical correction and balloon angioplasty of aortic coarctation in infants are effective and give a good immediate result. Balloon angioplasty may be an acceptable alternative to surgical treatment in infants with critical aortic coarctation, although it is accompanied with an increased level of re-coarctation. Recoarctation after balloon dilatation is manifested in the first 3-4 months of postoperative follow-up and requires repeated correction by a surgical or endovascular method.

Key words: aortic coarctation, balloon angioplasty, infants. 